\title{
THE
}

2012

\section{Rethinking Placental Transfusion and Cord Clamping Issues}

Judith S. Mercer

University of Rhode Island, jmercer@uri.edu

Debra A. Erickson-Owens

University of Rhode Island, dericksonowens@uri.edu

Follow this and additional works at: https://digitalcommons.uri.edu/nursing_facpubs

Terms of Use

All rights reserved under copyright.

\section{Citation/Publisher Attribution}

Mercer, Judith S. PhD, CNM, FACNM; Erickson-Owens, Debra A. PhD, CNM Rethinking Placental Transfusion and Cord Clamping Issues, The Journal of Perinatal \& Neonatal Nursing: July/September 2012 - Volume 26 - Issue 3 - p 202-217 doi: 10.1097/JPN.0b013e31825d2d9a Available at: https://doi.org/10.1097/JPN.0b013e31825d2d9a

This Article is brought to you for free and open access by the College of Nursing at DigitalCommons@URI. It has been accepted for inclusion in College of Nursing Faculty Publications by an authorized administrator of DigitalCommons@URI. For more information, please contact digitalcommons-group@uri.edu. 


\title{
Rethinking Placental Transfusion and Cord Clamping Issues
}

\author{
Judith S. Mercer, PhD, CNM, FACNM, Debra A. Erickson-Owens, PhD, CNM
}

\begin{abstract}
A brief delay in clamping the umbilical cord results in a placental transfusion that supplies the infant with a major source of iron during the first few months of life. Cord circulation continues for several minutes after birth and placental transfusion results in approximately $30 \%$ more blood volume. Gravity influences the amount of placental transfusion that an infant receives. Placing the infant skin-to-skin requires a longer delay of cord clamping (DCC) than current recommendations. Uterotonics are not contraindicated with DCC. Cord milking is a safe alternative to DCC when one must cut the cord prematurely. Recent randomized controlled trials demonstrate benefits for term and preterm infants from DCC. The belief that DCC causes hyperbilirubinemia or symptomatic polycythemia is unsupported by the available research. Delay of cord clamping substantively increases iron stores in early infancy. Inadequate iron stores in infancy may have an irreversible impact on the developing brain despite oral iron supplementation. Iron deficiency in infancy can lead to neurologic issues in older children including poor school performance, decreased cognitive abilities, and behavioral problems. The management of the umbilical cord in complex situations is inconsistent between birth settings. A change in practice requires collaboration between all types of providers who attend births.
\end{abstract}

Key Words: cord milking, delayed cord clamping, neonatal transition, placental transfusion, umbilical cord clamping

Author Affiliations: College of Nursing, University of Rhode Island, Kingston, Rhode Island; and The Warren Alpert Medical School of Brown University, Providence, Rhode Island

Disclosure: The authors have disclosed that they have no significant relationships with, or financial interest in, any commercial companies pertaining to this article.

Correspondence: Debra A. Erickson-Owens, PhD, CNM, College of Nursing, University of Rhode Island, White Hall, 2 Heathman Road, Kingston, RI 02882 (debeo@uri.edu).

Submitted for publication: February 17, 2012; accepted for publication: May 1, 2012.
etal to neonatal transition is a normal physiologic process - one that has occurred since the beginning of the human race. The physiologic changes that accompany this transition are so extreme that nothing short of death approaches them. For many, this time of transition breeds fear-people at birth often hold their breath awaiting the infant's first cry. Unfortunately, at times this fear drives one to interfere and disrupt the normal transition process. In the last century, as technology advanced, respect for the process of birth was lost in exchange for efficiency and expedience. Current research evidence has reexamined "old fashioned" practices, such as early breastfeeding and skin-to-skin placement, and discovered not only are these practices safe, but they are important for promoting mother and infant well-being. ${ }^{1}$ Immediate cord clamping (ICC), a fairly new birth practice, is very common in hospital settings throughout the world. ${ }^{2}$ Yet, a brief delay in clamping the umbilical cord results in a placental transfusion that supplies the infant with iron-rich red blood cells, additional blood volume, and millions of stem cells. Several decades ago, delayed cord clamping (DCC) at birth was discarded from mainstream practice without careful study or regard to the physiologic processes at work. It is time to rethink the practice of DCC because a delay in clamping the cord facilitates a gentle physiologic transition that benefits all neonates and may be critical especially to vulnerable infants. Plus important new research has demonstrated that DCC results in increased infant iron stores out to 6 months of age. This may prove to be a very important practice for the developing infant's brain.

This article examines the effects of placental transfusion when cord clamping is delayed or when the cord is milked and provides existing evidence from randomized controlled trials and physiologic studies. The physiology of transition is reviewed and clinical situations in which protecting placental blood flow is of particular importance are addressed. Recommendations for introducing 
a change in practice are discussed and issues requiring further research are identified.

\section{PHYSIOLOGIC EFFECTS OF PLACENTAL TRANSFUSION ON THE INFANT}

When cord clamping is delayed at birth or the cord is milked, infants experience placental transfusion as whole blood is transferred (or transfused) from the placenta to the infant during the first few minutes of life. This blood contains not only volume and red blood cells but also millions of stem cells important in repairing tissue and building immunocompetence. The red blood cells are a major source of iron during the first few months of life. ${ }^{3}$ When the cord is cut rapidly, the infant has no access to approximately $30 \mathrm{~mL} / \mathrm{kg}$ (of birth weight) of blood-about $30 \%$ of the fetal-placental blood volume. Placental transfusion facilitates an increase in the circulatory bed at the same time that the infant's various organs (lung, liver, kidney, etc) assume the many functions maintained by the placenta during fetal life. This additional blood volume may reduce the vulnerability of infants to inflammatory processes and provide protection against intection., ${ }^{4}$

\section{Fetal and neonatal blood volume}

Throughout pregnancy, blood flows in a continuous circuit from fetus to placenta (via the 2 umbilical arteries) and back to fetus (via the 1 umbilical vein). The fetal heart is the driver for this process, contracting with enough force to perfuse the most distant placental villi. The amount of whole blood in the fetal-placental circulation is estimated to be 110 to $115 \mathrm{~mL} / \mathrm{kg}$ of fetal weight throughout gestation. ${ }^{6,7}$ During fetal life, the blood flow to the lungs is only $10 \%$ of the fetal cardiac output. The placenta is the organ of respiration and it adequately oxygenates the fetus with more than $50 \%$ of the fetal cardiac output circulating through it at any one time. At birth, the cardiac output to the lungs must rapidly change from $10 \%$ to $45 \%-55 \%$ to adapt to air respiration in the newborn lungs. Delayed cord clamping delivers the volume of blood needed for this adaptation. The circulation in the cord continues for several minutes after birth and placental transfusion results in approximately $30 \%$ more blood volume compared with infants with ICC. ${ }^{8}$

\section{FACTORS THAT EFFECT THE AMOUNT OF PLACENTAL TRANSFUSION AT BIRTH}

In the first few minutes after birth, factors such as time, milking of the cord, gravity (where the infant is placed in relation to the placenta), and uterine contractions have been shown to cause a significant increase of blood transfer from the placenta to the infant at term and preterm births. Uterotonics speed up the placental transfusion but do not increase the overall amount of blood transfused.

\section{Timing of cord clamping}

Farrar et $\mathrm{al}^{9}$ estimated placental transfusion by measuring infant weight gain in the first 5 minutes after birth while the cord was left intact at vaginal and cesarean birth. ${ }^{9}$ The mean amount of placental transfusion was 81 $\mathrm{mL}$ (range, 50 to $163 \mathrm{~mL}$ ) or $25 \mathrm{~mL} / \mathrm{kg}$ (range, 16 to 45 $\mathrm{mL} / \mathrm{kg}$ ). The authors estimated that placental transfusion contributed to about $20 \%$ of the infant's blood volume at birth. ${ }^{9}$ This is supported by a classical work of Yao, ${ }^{8}$ which demonstrated that a term infant's blood volume is approximately $70 \mathrm{~mL} / \mathrm{kg}$ following ICC compared with approximately $90 \mathrm{~mL} / \mathrm{kg}$ with DCC (3 minutes).

Narenda ${ }^{10}$ was able to show that a brief delay in cord clamping ( -30 to 45 seconds) in preterm infants resulted in a $8 \%$ to $24 \%$ increase in blood volume ( 2 to $16 \mathrm{~mL} / \mathrm{kg}$ at cesarean birth and 10 to $28 \mathrm{~mL} / \mathrm{kg}$ at vaginal birth). ${ }^{10}$ In term and preterm births, a delay in the time of cord clamping results in more blood being transferred to the infant and it is proportional to the time delayed. ${ }^{8,9}$

\section{Gravity and positioning of the infant immediately after birth}

Gravity affects the amount of placental transfusion that an infant receives. ${ }^{11}$ Holding the infant above the level of the placenta $(>10 \mathrm{~cm})$ slows the placental transfusion and lowering the infant accelerates it. For example, placing an infant skin-to-skin on the maternal abdomen slows the rate of the placental transfusion. ${ }^{12}$ By measuring the amount of blood left behind in the placenta, after infants are placed skin-to-skin, a 2-minute delay in cord clamping results in only a partial placental transfusion. Figure 1 demonstrates that a 2-minute delay results in an average of $25 \mathrm{~mL} / \mathrm{kg}$ of whole blood left behind in the placenta compared with a 5-minute delay that leaves only an average of $11 \mathrm{~mL} / \mathrm{kg}$. A 5-minute delay in cord clamping allows the infant who is skin-to-skin to receive a full placental transfusion. ${ }^{12}$

\section{Uterine contractions}

During the few minutes surrounding birth, the maternal uterine contractions squeeze blood from the placenta to the infant. The reduced size of the uterus as the fetus descends, supports placental transfusion, and prevents "backflow" from the infant to the placenta. However, as the uterus relaxes between contractions, blood can flow through the placenta and exchange nutrients and oxygen. ${ }^{13,14}$ This role continues as long as the placenta 


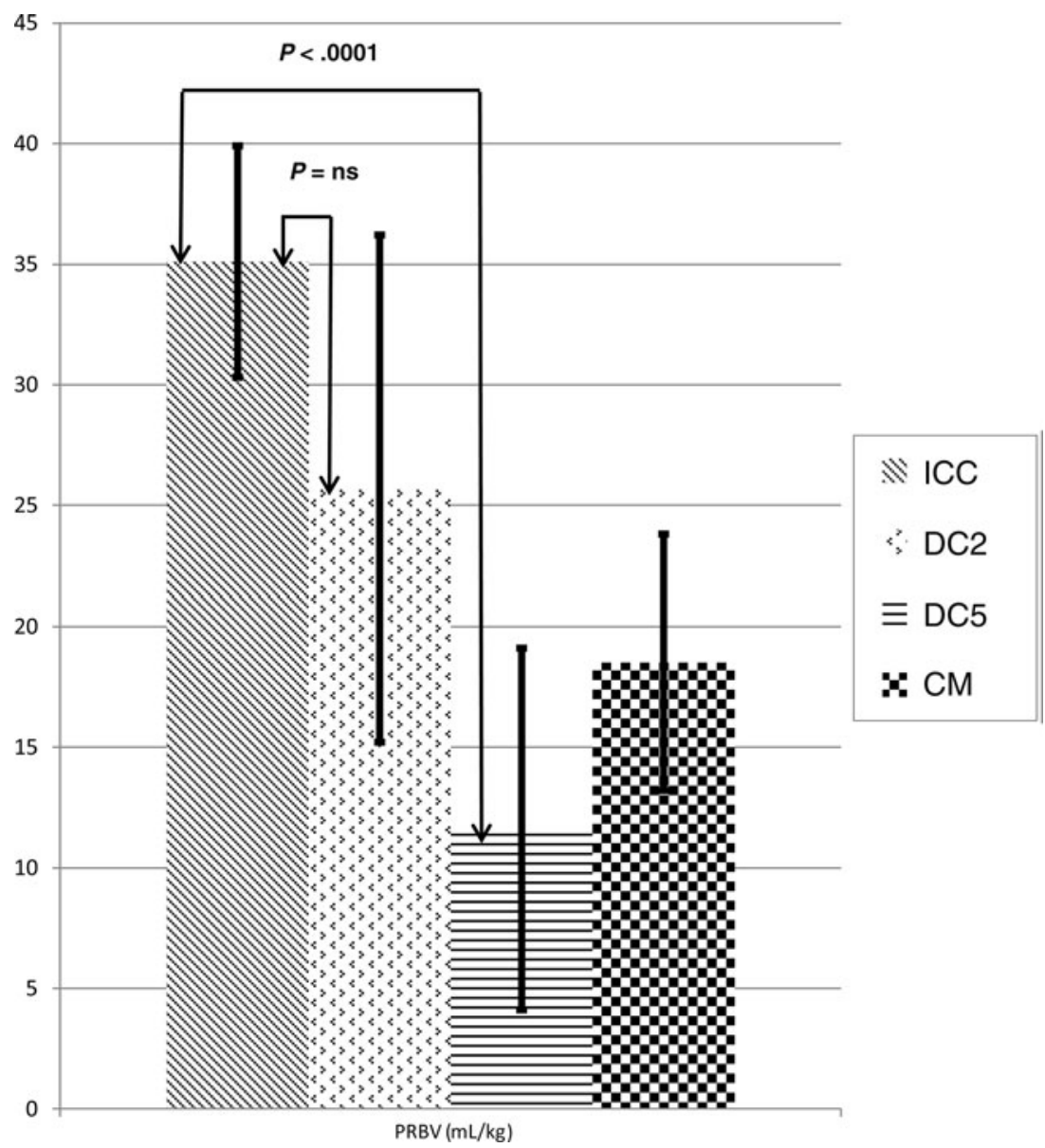

Figure 1. The amount of blood left behind in the placenta (placental residual blood volume [PRBV]) when term infants are held skin-to-skin after birth. CM, umbilical cord milking $\times 5$ times; DC2, delayed cord clamping $\times 2$ minutes; DC5, delayed cord clamping $\times 5$ minutes; ICC, immediate cord clamping. From Erickson-Owens et al. ${ }^{12}$

is attached to the uterine wall and is a valuable asset especially for the infant who is not breathing. Even after the umbilical arteries close, the strong uterine contractions of third stage force more of the placental blood to the infant via the umbilical vein if the cord is left intact. ${ }^{8,13}$

\section{Uterotonic drugs}

Use of a uterotonic drug with the birth of the anterior shoulder or soon after birth has been shown to significantly reduce the incidence of postpartum maternal hemorrhage ${ }^{15}$ but clinicians have expressed concern about the timing of uterotonic administration and its effect on placental transfusion. $\mathrm{Yao}^{16}$ and Farrar et $\mathrm{al}^{9}$ have demonstrated that uterotonics can be safely administered before the cord is clamped and cut. Yao ${ }^{16}$ demonstrated that a strong uterotonic drug administered intravenously at birth sped up the rate of placental trans- fusion but did not cause overtransfusion as some feared it would do. Farrar et $\mathrm{al}^{9}$ found no effect on the amount of placental transfusion following intravenous or intramuscular administration of oxytocin.

\section{Milking the umbilical cord}

Umbilical cord milking consists of stripping the cord from the placenta toward the infant several times. It is a viable alternative to DCC at birth when the clinical situation requires the provider to clamp and cut the umbilical cord quickly. The available cord milking studies of term infants ( 8 controlled trials and 1 randomized controlled trial) ${ }^{17-25}$ conclude that cord milking significantly improves hematocrit and hemoglobin levels in the first few days of life when compared with ICC, with no associated harm. This suggests cord milking effectively accelerates placental transfusion at the time of birth similar to DCC. 


\section{CURRENT EVIDENCE: EFFECTS OF PLACENTAL TRANSFUSION}

\section{Effects of DCC on full-term infants}

In the 11 years since the first integrative review, ${ }^{26}$ 4 systematic reviews, ${ }^{27-30} 9$ randomized controlled trials, ${ }^{14,31-38}$ and 2 secondary analyses ${ }^{39,40}$ have been published. The results are summarized in Appendix 1. Six of the studies followed the infants beyond the newborn period and found that DCC is a safe and effective means for reducing the risk of iron deficiency up to 6 months of age. ${ }^{14,31,33,35,36,38}$ Infants with ICC, born to anemic mothers in India, had a 7-fold increased risk of anemia and a 10-fold increased risk of lower iron stores at 3 months of age compared with infants exposed to DCC. ${ }^{38}$ In a study of healthy term Mexican infants ( $n$ $=358$ ) randomized to either ICC or DCC (2-minute delay, held below placenta), the DCC group had higher ferritin and total body iron stores at 6 months. ${ }^{35}$ The authors estimated that DCC of 2 minutes increased iron stores by 27 to $47 \mathrm{mg}$, enough for a 4- to 6-month supply. van Rheenen et $\mathrm{al}^{14}$ found that Zambian infants at 4 months of age $(n=91)$, whose cords were clamped after the cord stopped pulsating (mean time $=5.1 \mathrm{~min}$ utes), had significantly less anemia $(P=.05) .{ }^{14}$ In Sweden, Andersson et $\mathrm{al}^{31}$ found that at 4 months of age, although there were no differences in hemoglobin concentration between the groups, infants exposed to DCC had a $45 \%$ higher mean ferritin concentration $(117 \mu \mathrm{g} / \mathrm{L}$ vs $81 \mu \mathrm{g} / \mathrm{L}, P<.001)$ and a lower prevalence of iron deficiency $(1[0.6 \%]$ vs 10 [5.7\%], $P=.01) .{ }^{31}$ Thus, DCC has been shown to substantively increase blood volume following birth, leading to increased iron stores in early infancy and reducing the risk of iron deficiency. Table 1 summarizes the effects of DCC in term infants (from randomized controlled trials).

Physiologic studies, some conducted more than 40 years ago, have examined placental transfusion and re-

\section{Table 1. Effects of delayed cord clamping in term infants (from randomized controlled trials)}
Newborn Period
$\uparrow \mathrm{Hct}$ and $\mathrm{Hb}$ levels at 2 days of age $\mathrm{e}^{31,34,36}$
$\downarrow$ Anemia 32,36
No symptomatic polycythemia ${ }^{14,34,36,37}$
No difference in clinical jaundice ${ }^{14,37}$
At 3-6 Months of Age
$\uparrow$ Ferritin levels ${ }^{31,33,35,36,38}$
$\uparrow$ Total body iron stores ${ }^{35}$
$\downarrow$ Anemia $^{14,38}$
$\downarrow$ Lead levels in infants exposed to lead ${ }^{40}$

Abbreviations: $\mathrm{Hb}$, hemoglobin; Hct, hematocrit. port outcomes such as increased red cell volume, ${ }^{8,41}$ better cutaneous perfusion and higher skin temperature, ${ }^{42,43}$ increased renal blood flow resulting in more urine output and a greater ability to concentrate urine, ${ }^{44}$ as well as increased red blood cell flow to the brain and gut. ${ }^{45}$ This improved brain blood flow ( $12 \%$ to $20 \%$ ) was shown to continue for the first five days of life. ${ }^{45}$ Unfortunately, none of the available randomized controlled trials or physiologic research have examined the impact on infant and childhood neurodevelopmental outcomes.

\section{Effects of DCC on preterm infants}

Since 2000, 2 systematic reviews ${ }^{46,47}$ and 12 randomized controlled trials ( 2 with milking the cord $)^{48-59}$ have been published and offer information on DCC in preterm infants. Cord clamping protocols for DCC in preterm infants usually include a delay in clamping the umbilical cord (ranging 30 to 60 seconds) while holding the infant below the level of the placenta. The studies on DCC in preterm infants show absence of harm and include demonstrated benefits such a decrease in respiratory distress, ${ }^{60}$ less need for blood transfusion, ${ }^{48,59,61}$ and fewer cases of intraventricular hemorrhage and lateonset sepsis. ${ }^{53,62,63}$ In the latest meta-analysis of 10 studies, Rabe et $\mathrm{al}^{47}$ found reduced rates of neonatal transfusion for treating hypotension or anemia $(P<.005)$ and less intraventricular hemorrhage $(P<.002) .{ }^{47}$ One randomized controlled trial $(n=72)$ found an advantage for male infants in reducing intraventricular hemorrhage and sepsis. ${ }^{53}$ At 7 months corrected age, results indicated that if an infant was male and had DCC, his score on the Bayley's Scales of Infant and Toddler Development Psychomotor Development Index was significantly higher than if he had ICC. This finding suggests DCC is protective for very low-birth-weight male infants against motor disability at 7 months corrected age. ${ }^{64}$

\section{RISKS FROM PLACENTAL TRANSFUSION}

A widely held belief, often unreferenced in obstetrical and neonatal textbooks, is that there is a link between DCC, hyperbilirubinemia, and symptomatic polycythemia. Clinicians are concerned that babies will be "overtransfused." This belief is unsubstantiated by the current research. Recent evidence suggests DCC is a harmless practice. The issues of hyperbilirubinemia and polycythemia are more likely related to underlying pathologic events occurring within the fetus and/or newborn. Hyperbilirubinemia has been associated with preterm birth, hypoxia, hypoglycemia, polycythemia, poor feeding habits or feeding intolerance, and delayed passage of meconium. ${ }^{65}$ Symptomatic polycythemia is associated with a poor intrauterine environment resulting in an increased fetal production 
of erythrocytes (erythropoiesis). ${ }^{66}$ Known factors that cause erythropoiesis during pregnancy, resulting in polycythemia, include maternal diabetes, hypertension, cigarette smoking, postmaturity, newborn congenital anomalies, twin-to-twin transfusion, and intrauterine growth restriction. ${ }^{66-70}$

None of the randomized controlled trials published since 1980 have supported a link between DCC and hyperbilirubinemia or symptomatic polycythemia. ${ }^{14,31-38,71-74}$ Results of studies reporting the incidence of jaundice and polycythemia in full-term infants are summarized in Appendix 2. A systematic review published by McDonald and Middleton ${ }^{29}$ suggested that there was a significantly higher rate of jaundice requiring phototherapy in DCC infants. ${ }^{29}$ However, this finding surfaced only with the weighted results of an unpub-

lished 1996 dissertation by McDonald. This thesis did not report bilirubin levels or masking of pediatricians and has not been peer reviewed. A 2007 systematic review by Hutton and Hassan, ${ }^{28}$ looking at similar studies did not identify any differences in rates of clinical jaundice or jaundice requiring treatment. Although a slight increase in asymptomatic polycythemia did occur as a result of DCC, it appeared to be benign. ${ }^{28}$

\section{POTENTIAL BENEFITS FROM PLACENTAL TRANSFUSION}

In light of the recent findings of improved iron stores and increased knowledge about stem cells, it is probable that DCC at birth or milking the cord offers significant benefits to the newborn and may play a neuroprotective role related to increased iron stores.

\section{The role of red blood cells and iron}

Placental transfusion at birth offers the infant the benefit of a 4- to 6-month supply of iron from the additional red blood cells. Because the fetus requires a large red blood cell mass to provide sufficient oxygen for normal growth and development, fetal erythropoietic activity is especially high. ${ }^{3}$ In a full-term infant at birth, the hemoglobin and hematocrit levels are generally higher than at any other time in life averaging $170 \mathrm{~g} / \mathrm{L}$ or 17 $\mathrm{mg} / \mathrm{dL}^{3}$ In addition, the fetus stores iron in the liver (and less so in the spleen and kidney), particularly in the last 8 weeks of gestation. The placenta removes iron for the fetus from the maternal circulation at the expense of maternal iron stores. When the mother is anemic or iron deficient, fetal iron deposition appears to suffer. ${ }^{75}$ Delayed cord clamping allows the transfer of up to $30 \mathrm{~mL} / \mathrm{kg}$ of blood from the placenta to the infant and the infant benefits from a $40 \%$ to $60 \%$ increase in red cell volume compared with the infant who has ICC. ${ }^{8,10,12}$ Because each gram of hemoglobin contains
$3.47 \mathrm{mg}$ of iron, the additional red blood cells obtained from DCC supply approximately 35 to $75.5 \mathrm{mg}$ of iron for the infant. ${ }^{3}$ That amount is sufficient to maintain desirable levels of tissue and circulatory iron for 3 to 4 months longer than if the infant has ICC. The question is, what effect, if any, do the higher iron stores have on the infant's current and future health and well-being? Although no studies of infants with DCC or ICC have reported findings beyond 6 months of age, long-term studies of children who had iron deficiency in infancy clearly show detrimental effects.

Human and animal comparison studies suggest inadequate iron stores in infancy may have an irreversible impact on the developing brain that persists well after iron stores have been replaced by iron supplementation. ${ }^{76-78}$ In a group of 9- to 12-month-old children ( $\overline{\bar{n}} 162)$, Lozoff $^{77}$ found that infant social-emotional behavior appeared to be adversely affected by iron deficiency with or without anemia. Children with poor iron status were found to be more shy, have a less positive affect, be more difficult to soothe, and had a reduced level of engagement with examiners. ${ }^{79}$ Significant differences in social-emotional scores remained between iron deficient and iron sufficient children even after an intervention program that improved the overall social-emotional test scores. ${ }^{80}$

Neurologic signs found in older children who had iron deficiency as infants include poor school performance, decreased cognitive abilities, behavioral problems, and lower executive function. ${ }^{81}$ Sleep alterations were still apparent in children years after correction of anemia of infancy with iron treatment and in the absence of subsequent iron deficiency anemia. ${ }^{82,83}$ Lozoff et $\mathrm{al}^{78}$ found that anemia of infancy, even when treated with iron, resulted in lower IQs, less favorable neurodevelopmental outcomes and more behavioral problems out to 19 years of age. ${ }^{78}$ The effects were more severe in children of poverty. Study participants with iron deficiency in infancy and with a middle socioeconomic status, scored about 8 points lower in IQ (101 vs 109) than the group with good iron status in infancy; this difference remained stable over time. For children of lower socioeconomic status, the gap widened from 10 points (93 vs 103) at 5 years of age to 25 points (70 vs 95) at 19 years. $^{78}$

How might low iron stores in infancy affect the brain? Infancy represents the most critical period of brain growth and myelin development. Most of the brain's eloquent neural pathways are established and refined during the first year of life. Myelin, a fatty sheath deposited by oligodendrocytes around the nerve's axon, provides insulation to foster effective conduction of nerve impulses. This enables better tissue connectivity within specific brain regions and also improves broader 
neural pathways connecting spatially separate regions required for many sensory, cognitive, and motor functions. Myelinated axons are white in appearance making up the brain's white matter. Iron plays an essential, though not fully understood, role in oligodendrogenesis and myelination. ${ }^{84}$ Oligodendrocytes, the cells that make myelin, are particularly sensitive to low iron levels that inhibit their growth. ${ }^{76}$

Sensitive periods in brain development require adequate iron stores ${ }^{84}$ Poor iron stores in the first year of life are known to harm the developing brain as myelination, hippocampus, and cortical brain development peak. ${ }^{76,85}$ Murine pups with iron deficiency have been shown to have hypomyelination and neurologic damage. ${ }^{76} \mathrm{In}$ humans, abnormal white matter development (myelination) has been associated with a variety of developmental disorders ranging from dyslexia to autism thus making it a key area of interest for further study. The persistence of poorer cognitive, motor, affective, and sensory system functioning in children who were anemic as infants highlights the need to study ways to prevent iron deficiency in infancy. ${ }^{86}$ Delayed cord clamping or milking the cord at birth may make an important contribution in the prevention of iron deficiency.

\section{Stem cells}

In addition to red blood cells, fetal blood contains large numbers of highly activated hematopoietic stem cells along with endothelial cell precursors, mesenchymal progenitors, and multipotent/pluripotent lineage stem cells many of which are lost to the infant with ICC. ${ }^{87}$ Stem cells play an essential role in organ development of the central nervous, respiratory, cardiovascular, hematologic, immunologic, and endocrine systems. ${ }^{87}$ Only at birth will a human being have such a high number of circulating stem cells. The reason is that hematopoiesis moves from the yolk sac to the liver during fetal life and to the bone marrow after birth. Thus, at birth, many more stem cells are in circulation and have not yet settled in the bone marrow where they will reside until recruited. The concentration of stem cells is much higher in the blood of premature infants compared with full-term infants.

The hematopoietic stem cells found in human cord blood have incredible potential for healing. They have been used successfully to treat a wide variety of hemoglobinopathies, metabolic and hematologic disorders, immune deficiencies, and cancers. In animal models, they have been found to repair heart, brain, liver, lung, muscle, and endothelial cells (lining blood vessels), and can prevent cerebral palsy when administered within 24 hours of an injury in rats. ${ }^{88}$ Experiments are underway using autologous stem cells collected at birth to treat cerebral palsy, type 1 diabetes, and hypoxic-ischemic encephalopathy in newborns (www.clinicaltrials.gov). There are no longitudinal studies of human infants who have kept their own stem cells at birth through DCC compared with those who were exposed to ICC..$^{87}$ The question must be asked: Does placental transfusion and the transfer of stem cells at birth play a role in the prevention of some diseases in infancy, childhood, and later in life?

Tolosa et $\mathrm{al}^{87}$ argue that "artificial loss of stem cells at birth could ... predispose infants to diseases such as chronic lung disease, asthma, diabetes, cerebral palsy, infection, and neoplasm."(p491) The authors of this article suggest the hypothesis that a newborn should obtain his or her full allotment of available stem cells at birth and this can be facilitated by placental transfusion (DCC or by milking the cord). If the labor and birth was in anyway traumatic for the infant, it is possible that the stem cells may assist with healing.

As randomized controlled trials provide more evidence of improved iron stores without associated adverse outcomes from DCC, many midwives and physicians are either adopting or considering adopting the practice particularly when requested by parents. The following discussion offers support and lessons learned for the introduction of the change in cord clamping practice within a facility.

\section{CREATING A CHANGE IN PRACTICE}

Instituting a change from the dominant practice of ICC requires that all staff working in a birthing/labor and delivery setting be involved. Birth encompasses many disciplines-obstetrics, midwifery, nursing, and pediatrics-all hold differing views about management of the umbilical cord at birth. To facilitate change, a change agent is needed to serve as catalyst to organize the effort and monitor progress. The change agent may want to start with a theory focused on introducing and sustaining change such as Lewin's Three Step Change Theory (Figure 2 ) ${ }^{89}$ It will help to understand

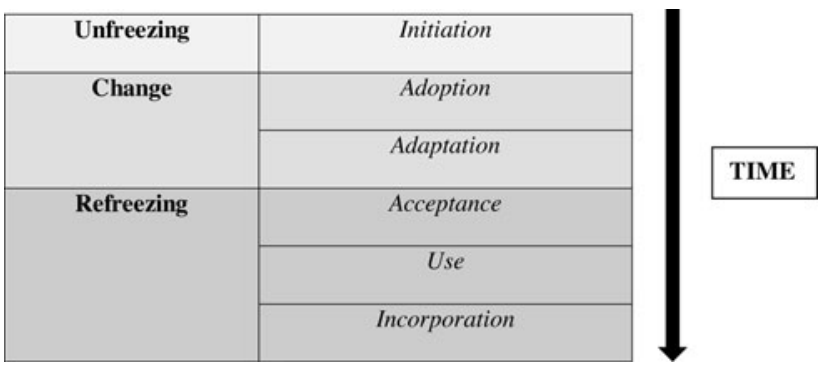

Figure 2. Lewin's Three Step Change Theory. Used with permission from Keller. ${ }^{89}$ 
how to conduct the process, add a realistic time frame, and sustain a level of enthusiasm. The leadership of each professional group needs to be involved from the beginning. Lewin's first step suggests initiating the information so as to shake up (unfreeze) the status quo (equilibrium) by presenting the current best evidence for and against the issue. Two comprehensive reviews of the literature (see Appendices 1 and 2) have been included to assist with this effort. This requires building recognition of the need for change and persuading staff that the status quo is not beneficial for infants and may even be harmful. This is best accomplished by beginning with a small group of leaders to start discussions of the evidence. It can also be supplemented by inviting an expert to lead Grand Rounds or run a workshop focused on DCC as an evidence-based birth practice. Distributing current literature, introducing an article at a journal club or having one-on-one conversations can be helpful. Over time, a "best practice recommendation" consensus should be developed and shared.

The second step of Lewin's Change Theory, changeadoption and adaptation, involves introducing the practice and monitoring the progress. The establishment of trust is key and striving to build trust and excellent communication with all parties is essential. Documentation of the change process will highlight strengths and weaknesses. The group may introduce the new policy with careful recording of what happens in a limited number of cases. This can then be reviewed for discussion of problems that arise with appropriate adjustments before the policy is recommended for all providers.

The third step is refreezing--developing a new policy that will sustain the change over time. This requires acceptance and use of the policy and integration of the new values into the culture of the setting. New patterns are reinforced and institutionalized through formal and informal mechanisms including policies and procedures. Figure 3 follows the process of how one institution changed practice and adopted DCC as a best birth practice (Dr B. Spetalnick, e-mail communication, February 14, 2012).

\section{COMPLEX SITUATIONS}

When birth is normal, a provider can independently decide to use DCC when and if they wish. Conflict arises when that provider is confronted with more complex situations such as a nuchal cord, shoulder dystocia, a slow-to-start infant, and the need for resuscitation. Is it possible to resuscitate an infant at the perineum with an intact cord and still follow the Neonatal Resuscitation Program (NRP) guidelines $?^{90}$ Can one obtain a blood gas without clamping and cutting the cord? Is cord blood harvesting compatible with DCC?
Incorporating DCC as a Best Practice (framed within Lewin's Change Theory)

\section{Lewin's Step 1: UNFREEZING}

The initial push for a change in practice

- A senior neonatologist queries pediatric and obstetric colleagues about the practice of DCC in preterm infants via listserve and offers a talk he will present on the current evidence about the use of DCC in babies $<32$ weeks. He believes the evidence is sufficient to change practice.

- There are a few negative email responses which specifically suggest when not to use DCC such as with meconium, during cesarean section and when resuscitation is required.

- Email listserve expands to nurse-midwives, maternal fetal medicine and the nurse educator. A strong recommendation is made that all disciplines must be involved in the discussion.

- Email discussion that if the DCC is accepted, then a plan must be developed to inform across disciplines-students, residents, L\&D nurses, obstetricians, midwives and pediatricians.

- Senior $\mathrm{OB}$ leadership sends an email expressing no concerns and agreement with the recommendations.

- The university's Center for Evidence-Based Medicine reviews the available research evidence and supports the recommendation for preterm infants.

After Two Months

- Momentum slows down. The Chairman of OB asks what has happened to the issue of DCC

$\sim 12$ Months

- A nurse-midwife recommends adoption of the practice for term babies based on the Hutton and Hassan review (2007) which suggests DCC for at least two minutes.

The Medical Director for L\&D feels the literature is convincing and the practice should be considered. A recommendation is made to develop a "best practice" proposal and submit to the OB-Patient Care Committee.

$\sim 16$ Months Lewin's Step 2: CHANGE

- The proposal is accepted. It is recommended that best practice at term birth includes at least a two minute delay in cord clamping. Lewin's Step 3: REFREEZING

$\sim 57$ Months

- A revised DCC Best Practice Recommendation, which added a protocol for preterm newborns, is passed unanimously by the OB-Patient Care Committee. The Medical Director for L\&D reports DCC is included as a L\&D Best Practice Recommendation. DCC is taught to the interns and residents. Providers document electronically in the delivery note: "Cord clamped and cut after 2 minutes: Yes or No. If no, reason: _ . Compliance has gone well. There has been a dramatic rise in the percentage of infants who received DCC since the Best Practice Recommendation was implemented. In 2011, 59.2\% of all infants received DCC compared to $39.5 \%$ of all infants in 2007 .

Figure 3. Changing practice at a US medical center (Dr B. Spetalnick, e-mail communication, February 14, 2012). DCC, delayed cord clamping.

\section{Resuscitation with an intact cord}

Most midwives and physicians who practice in out-ofhospital settings, especially at home, resuscitate infants at the perineum with the cord intact. Providers whose practice paradigm is to support a more physiologic transition prefer to leave the cord intact even with an infant who needs resuscitation. They believe that the infant continues to receive placental support during the immediate transition, including when resuscitation is needed. ${ }^{91}$ This procedure allows the infant to be physiologically supported via continued placental respiration while resuscitation is underway. It does not seem logical to cut the cord immediately and remove a nonbreathing infant from his only source of respiratory support. ${ }^{92}$ For providers who believe in the benefit of DCC and/or have promised the parents to delay clamping, a conflict arises when they are confronted with a pale, limp infant who is slow to start and needs resuscitation.

Although this practice paradigm is most commonly found in birth center and home settings, many providers 
practice in all 3 settings and this can lead to a conflict between practice modes and settings. These providers risk a backlash in the hospital setting if they do not cut the cord right away even when they feel it may cause the infant harm. Immediately clamping the cord and moving a depressed infant to the warmer feels counterintuitive and the demand to do so creates an ethical dilemma.

Adult CPR has recently adopted cardiocerebral resuscitation with an emphasis on blood volume to maintain perfusion to the heart and brain..$^{93,94}$ This is a critical factor in protecting brain and heart function and improving survival. The new adult recommendations support continuous chest compressions to circulate blood without interruption for ventilations. ${ }^{93}$ Research, using animal models, has shown that cardiac arrest survival increased up to $80 \%$ when perfusion was supported by continuous chest compressions compared with $13 \%$ with standard cardiopulmonary resuscitation. ${ }^{94}$ If this is adapted to infants, it becomes clear that blood volume is also critical to adequately perfuse their hearts and protect their brains. ${ }^{95}$ Resuscitating an infant at the perineum, with an intact umbilical cord, allows the infant access up to $30 \%$ more blood volume--a step that may be essential for recovery. The limp, pale, nonbreathing infant is often hypovolemic but via DCC can benefit from additional blood and red cell volume while resuscitation is proceeding.

Three physicians from the United Kingdom are advocating for a resuscitation plan known as BASICS (Bedside Assessment, Stabilization, and Immediate Cardiorespiratory Support), which facilitates bedside resuscitation of the infant while leaving the umbilical cord intact. ${ }^{96-98}$ If one uses the BASICS principles and resuscitates an infant with the cord intact; it allows the sequestered placental blood to be transfused to the infant. Returning this blood is a vital mechanism to revive a depressed (often hypovolemic) newborn. All recommendations in the NRP can be followed while the infant is still attached to the placenta. ${ }^{14,96}$ The authors recommend placing the infant on a clean, dry pad on the bed between the mother's legs so that there is no tension on the cord. If the bed is broken, one can hold the infant below the perineum $(\geq 30 \mathrm{~cm})$. However, access to the infant is more difficult in this position. If one must "cut and run," the cord can be milked several times to accelerate placental transfusion to the infant. As the infant's blood volume is restored, muscle tone usually returns simultaneously.

\section{Tight nuchal cord management: somersault maneuver}

A nuchal cord occurs in up to $30 \%$ of all births. A tight nuchal cord occurs significantly less often. Infants with a tight nuchal cord usually experience some degree of hypovolemia. ${ }^{99-102}$ To assist in restoring blood volume, Mercer et $\mathrm{al}^{101}$ recommends using the somersault maneuver. Schorn and Blanco ${ }^{103}$ first introduced the somersault maneuver as an alternative to the usual practice of ICC when a tight nuchal cord is encountered. The somersault maneuver involves holding the infant's head close to the perineum as birth occurs while "somersaulting" the body so that the infant's feet end up toward the mother's knees. The cord can then be unwrapped while preserving the integrity of the cord allowing resuscitation at the perineum to reverse hypovolemia should it be needed. ${ }^{101,103}$

\section{Shoulder dystocia}

Shoulder dystocia may place infants at risk for hypovolemia. The squeeze of a tight fit through the birth canal may cause more of the fetal blood to be sequestered in the placenta. ${ }^{95,104}$ This may account for the poor condition of many of these infants at birth-worse than what would be anticipated from shoulder dystocia alone. ${ }^{105}$ The rapid cutting of the cord to facilitate resuscitation at the warmer may in fact be a harmful practice.

Shoulder dystocia and the presence of a tight nuchal cord can be especially dangerous for a newborn. Iffy published 2 reviews of shoulder dystocia $(n=9)$ where the nuchal cord was cut before the birth. ${ }^{100,106}$ All births occurred within 3 to 7 minutes after the delivery of the head. All had normal labor and no evidence of fetal distress prior to birth but all had poor Apgar scores and 7 out of 9 infants later developed cerebral palsy.

Flamm ${ }^{107}$ reported the birth of an infant where he almost cut the nuchal cord before he was assured that the infant would be born. He was able to slip the cord over the head. However, he was unable to deliver the infant vaginally. He used the Zavanelli maneuver to replace the head. The infant was born by cesarean section and had Apgar scores of 3 at 1 minute, 7 at 5 minutes, and 9 at 10 minutes. Cutting a nuchal cord prior to the birth of the shoulders may increase an infant's risk of asphyxia and even death if there is a severe shoulder dystocia. ${ }^{106,107}$

\section{Cord blood gas collection}

Within a hospital setting, the practice culture may require umbilical cord gas collection at each birth or at least in a select group of infants. Cord gas collection is perceived by some as a necessary evolution within a highly litigious practice environment. Cord gases provide an objective measure of metabolic status at the time of birth but the sample is usually drawn immediately after birth and implies ICC. ${ }^{108}$ This practice overlooks the vital contribution of blood volume and the oxygen-carrying capacity of red blood cells achieved through placental transfusion as the fetus adapts to neonatal life. ${ }^{96,109}$ The practice of placental transfusion 
and the collection of umbilical cord blood gases are not necessarily mutually exclusive. Andersson et $\mathrm{al}^{31}$ report collecting cord gases routinely, but instead of ICC, a cord gas sample (arterial and venous) was drawn from an intact cord while a full placental transfusion was occurring. ${ }^{31}$ The blood gas collection needles were small enough that their puncture holes closed immediately.

Published literature that examines the impact of placental transfusion on arterial blood gases has not made strong clinical recommendations about when to cut the cord. However, all have stressed that blood gas values begin to lose their reliability after 15 to 30 minutes. ${ }^{110,111}$ Wiberg et $\mathrm{al}^{49}$ suggest that a delay of 90 seconds before clamping the cord has little significance on arterial $\mathrm{pH}$ in healthy newborns. ${ }^{49}$ In those clinical situations where fetal compromise is suspected and the provider feels he or she must cut and run, the cord can be milked first before clamping. Milking the cord allows appropriate cord gas sampling while supporting placental transfusion.

\section{Cord blood collection}

Blood banks designed to save the infant's stem cells for the future are aggressively marketed to parents and providers and have been established without any longterm research on the safety or impact. Immediately clamping and cutting the umbilical cord usually yields a high volume of blood (preferred by blood banks) compared with collection after DCC, which may yield 30 to $60 \mathrm{~mL}$ of cord blood. Current stem cell transfusion technology is beginning to combine cord blood donations to obtain enough cells for a transfusion thus supporting idea of the collection of smaller samples. Immediate cord clamping prevents the infant from receiving a full allotment of stem cells at birth. The authors recommend against ICC, which results in large collections and questions the ethics of using the newborn as a blood donor. An adult donates no more than $10 \%$ of his or her blood volume at one time. For infants, ICC can result in a donation of up to $30 \%$ of the fetal-placental blood. A child is not allowed to be a blood donor in this country. This should also include all infants. The practice of collecting a large amount of placental blood from an infant at birth needs reexamination. There have been no studies looking at long-term consequences of this practice. It is time to rethink large quantities of infant blood donation at the time of birth. Collection of stem cells at birth versus placental transfusion is a topic about which parents should be fully informed in the prenatal period. ${ }^{112}$

\section{Recommendations for practice}

At a normal birth, the provider can place the infant skinto-skin, dry and cover the infant with a warm blanket, and leave the umbilical cord intact until the placenta is ready to deliver. When perfusion is complete, the cord will become pale, white, and flat and look obviously emptied. One caveat is that only infants with good tone should go immediately onto the maternal abdomen.

When an infant has poor tone or is "slow to start," the infant can be placed on a clean pad at the perineum or held below the level of the placenta. The heart rate should be assessed. The rate is generally normal even though the infant may not be breathing. As long as the heart rate is normal, then resuscitation, as recommended by the NRP, can proceed but at the perineum (with an intact cord), rather than on the warmer. Once the infant is breathing and tone is regained, the infant can be placed skin-to-skin.

If the heart rate is low, the cord can be milked several times toward the infant to accelerate transfer of blood volume. The heart rate should be checked again and if not improved, all the usual resuscitation maneuvers can be instituted at the perineum without detaching the infant. This method of resuscitation has been practiced for many years in out-of-hospital settings. ${ }^{91}$

\section{SUMMARY}

This article offers high quality evidence that shows that receiving a placental transfusion at birth protects the infant from low iron stores and anemia during the first 6 months of life - a time of maximum brain growth. Iron deficiency is associated with hypomyelination and less favorable developmental outcomes but long-term effects related to placental transfusion have not been studied. Techniques to facilitate placental transfusion at the time of normal birth as well as in complex practice situations needs the support of informed change agents to foster the introduction of practice change into all labor and birthing units. It is time to rethink the management of the umbilical cord during the critical time of fetal to neonatal transition.

\section{References}

1. Section on Breastfeeding. Breastfeeding and the use of human milk. Pediatrics. 2012;129:e827-e841.

2. Chaparro CM. Timing of umbilical cord clamping: effect on iron endowment of the newborn and later iron status. Nutr Rev. 2011;69(suppl 1):S30-S36.

3. Dewey KG, Chaparro CM. Session 4: mineral metabolism and body composition iron status of breast-fed infants. Proc Nutr Soc. 2007;66:412-422.

4. Molitoris BA, Sutton TA. Endothelial injury and dysfunction: role in the extension phase of acute renal failure. Kidney Int. 2004;66:496-499.

5. Rajnik M, Salkowski CA, Thomas KE, Li YY, Rollwagen FM, Vogell SN. Induction of early inflammatory gene expression in a murine model of nonresuscitated, fixed-volume hemorrhage. Shock. 2002;17:322-328.

6. Wardrop CAJ, Holland BM. The roles and vital importance of placental blood to the newborn infant. J Perinat Med. 1995;23:139-143. 
7. Linderkamp O. Placental transfusion: determinants and effects. Clin Perinat. 1982;9:559-92.

8. Yao AC, Moinian M, Lind J. Distribution of blood between infant and placenta after birth. Lancet. 1969;2:871-873.

9. Farrar D, Airey R, Law GR, Tuffnell D, Cattle B, Duley L. Measuring placental transfusion for term births: weighing babies with cord intact. BJOG. 2011;118:70-75.

10. Narenda A, Beckett C, Aitchison T, et al. Is it possible to promote placental transfusion at preterm delivery? Pediatr Res. 1998;44:453.

11. Yao AC, Lind J. Effect of gravity on placental transfusion. Lancet. 1969;2:505-508.

12. Erickson-Owens D. Placental Transfusion at Birth in FullTerm Infants. Original research presented at the 6th Annual Normal Labour and Birth Conference, Grange-Over-Sands, England; 2011.

13. Caldeyro Barcia R, Alvarez H, Amador Fernandez R. A better understanding of uterine contractility through simultaneous recording with an internal and a seven channel external method. Surg Gynecol Obstet. 1950;91:641-646.

14. van Rheenen P, de Moor L, Eschbach S, de Grooth H, Brabin B. Delayed cord clamping and haemoglobin levels in infancy: a randomised controlled trial in term babies. Trop Med Int Health. 2007;12:603-616.

15. Prendiville WJ, Elbourne D, McDonald S. Active versus expectant management in the third stage of labour. Cochrane Database Syst Rev. 2000;3:CD000007.

16. Yao AC, Lind J. Blood flow in the umbilical vessels during the third stage of labor. Biol Neonate. 1974;25: 186193.

17. McCausland A, Holmes F, Schumann W. Management of cord and placental blood and its effect upon the newborn. Part I. Trans Pac Coast Obstet Gynecol Soc. 1949;17:87-104.

18. Siddall R, Crissey R, Knapp W. Effect on cesarean section babies of stripping or milking of the umbilical cord. Am J Obstet Gynecol. 1952;63:1059-1064.

19. Siddall R, Richardson R. Milking or stripping the umbilical cord; effect on vaginally delivered babies. Obstet Gynecol. $1953 ; 1: 230-233$.

20. Colozzi AE. Clamping of the umbilical cord; its effect on the placental transfusion. New Engl J Med. 1954;250: 629632.

21. Whipple GA, Sisson TR, Lund CJ. Delayed ligation of the umbilical cord; its influence on the blood volume of the newborn. Obstet Gynecol. 1957;10:603-610.

22. Lanzkowsky P. Effects of early and late clamping of umbilical cord on infant's haemoglobin level. Br Med J. 1960;2:17771782.

23. Usher R, Shephard M, Lind J. The blood volume of the newborn infant and placental transfusion. Acta Paediatr. 1963;52:497-512.

24. Walsh SZ. Early clamping versus stripping of cord: Comparative study of electrocardiogram in neonatal period. Br Heart J. 1969;31:122-126.

25. Erickson-Owens DA, Mercer JS, Oh W. Umbilical cord milking in term infants delivered by cesarean section: a randomized controlled trial [published online ahead of print November 17, 2011]. J Perinatol. doi:10.1038/jp.2011.159.

26. Mercer J. Current best evidence: a review of the literature on umbilical cord clamping. J Midwifery Womens Health. 2001;46:402-414.

27. van Rheenen $\mathrm{P}$, Brabin BJ. Late umbilical cord-clamping as an intervention for reducing iron deficiency anaemia in term infants in developing and industrialised countries: a systematic review. Ann Trop Paediatr. 2004;24:3-16.

28. Hutton EK, Hassan ES. Late vs early clamping of the umbilical cord in full-term neonates: systematic review and metaanalysis of controlled trials. JAMA. 2007;297:1241-1252.
29. McDonald SJ, Middleton P. Effect of timing of umbilical cord clamping of term infants on maternal and neonatal outcomes. Cochrane Database Syst Rev. 2008;CD004074.

30. Mathew JL. Timing of umbilical cord clamping in term and preterm deliveries and infant and maternal outcomes: a systematic review of randomized controlled trials. Indian Pediatr. 2011;48:123-129.

31. Andersson O, Hellstrom-Westas L, Andersson D, Domellof M. Effect of delayed versus early umbilical cord clamping on neonatal outcomes and iron status at 4 months: a randomized controlled trial. BMJ. 2011;343:d7157.

32. Jaleel R, Deeba F, Khan A. Timing of umbilical cord clamping and neonatal haematological status. J Pak Med Assoc. 2009;59:468-470.

33. Venancio SI, Levy RB, Saldiva SRDM, Mondini L, Alves MCGP, Leung SL. Effects of delayed cord clamping on hemoglobin and ferritin levels in infants at three months of age. Cad Saude Publica. 2008;24(suppl 2):S323-S331.

34. Jahazi A, Kordi M, Mirbehbahani NB, Mazloom SR. The effect of early and late umbilical cord clamping on neonatal hematocrit. J Perinatol. 2008;28:523-525.

35. Chaparro CM, Neufeld LM, Alavez TA, Cedillo RE-L, Dewey $\mathrm{K}$. Effect of timing of umbilical cord clamping on iron status in Mexican infants: a randomised controlled trial. Lancet. 2006;367:1997-2004.

36. Ceriani Cernadas JM, Carroli G, Pellegrini L, et al. The effect of timing of cord clamping on neonatal venous hematocrit values and clinical outcome at term: a randomized controlled trial. Obstet Gynecol Surg. 2006;61:564-565.

37. Emhamed MO, van Rheenen P, Brabin BJ. The early effects of delayed cord clamping in term infants born to Libyan mothers. Trop Doct. 2004:34:218-222.

38. Gupta R, Ramji S. Effect of delayed cord clamping on iron stores in infants born to anemic mothers: a randomized controlled trial. Indian Pediatr. 2002;39:130-135.

39. Ceriani Cernadas JM, Carroli G, Pellegrini L, et al. The effect of early and delayed umbilical cord clamping on ferritin levels in term infants at six months of life: a randomized, controlled trial. Arch Argent Pediatr. 2010;108:201-208.

40. Chaparro CM, Fornes R, Neufeld LM, Tena Alavez G, Egu' 1aL'1z Cedillo R, Dewey KG. Early umbilical cord clamping contributes to elevated blood lead levels among infants with higher lead exposure. J Pediatr. 2007;151:506-512.

41. Yao AC, Hirvensalo M, Lind J. Placental transfusion-rate and uterine contraction. Lancet. 1968;1:380-383.

42. Oh W, Lind J. Body temperature of the newborn infant in relation to placental transfusion. Acta Paediatr Scand. 1967; 172S: $137-145$.

43. Pietra GG, D'Amodio MD, Leventhal MM, Oh W, Brando JL. Electron microscopy of cutaneous capillaries of newborn infants: effects of placental transfusion. Pediatr. 1968;42:678683.

44. Oh W, Oh MA, Lind J. Renal function and blood volume in newborn infant related to placental transfusion. Acta Paediatr Scand. 1966;55:197-210.

45. Nelle M, Zilow EP, Bastert G, Linderkamp O. Effect of Leboyer childbirth on cardiac output, cerebral and gastrointestinal blood flow velocities in full-term neonates. Am J Perinatol. 1995;12:212-216.

46. Rabe H, Reynolds G, Diaz-Rossello J. Early versus delayed umbilical cord clamping in preterm infants. Cochrane Database Syst Rev. 2004:4:CD003248.

47. Rabe H, Reynolds G, Diaz-Rossello J. A systematic review and meta-analysis of a brief delay in clamping the umbilical cord of preterm infants. Neonatology. 2008;93:138-144.

48. Hosono S, Mugishima H, Fujita H, et al. Umbilical cord milking reduces the need for red cell transfusions and improves neonatal adaptation in infants born at less than 29 weeks' 
gestation: a randomised controlled trial. Arch Dis Child Fetal Neonatal Ed. 2008;93:F14-F19.

49. Wiberg N, Källén K, Olofsson P. Delayed umbilical cord clamping at birth has effects on arterial and venous blood gases and lactate concentrations. BJOG. 2008;115:697-703.

50. Strauss RG, Mock DM, Johnson KJ, et al. A randomized clinical trial comparing immediate versus delayed clamping of the umbilical cord in preterm infants: short-term clinical and laboratory endpoints. Transfusion. 2008;48:658-665.

51. Minami H. Cord milking reduces the need for blood transfusions and the incidence of severe intraventricular hemorrhage in infants born before 26 weeks of gestation. PAS. 2008; Abstract 4450 .

52. Baenziger O, Stolkin F, von Siebenthal K, et al. The influence of the timing of cord clamping on postnatal cerebral oxygenation in preterm neonates: a randomized controlled trial. Pediatrics. 2007;119:455-459.

53. Mercer JS, Vohr BR, McGrath MM, Padbury JF, Wallach $\mathrm{M}$, Oh W. Delayed cord clamping in very preterm infants reduces the incidence of intraventricular hemorrhage and lateonset sepsis: a randomized, controlled trial. Pediatrics. 2006; 117:1235-1242.

54. Aladangady $\mathrm{N}$, McHugh S, Aitchison TC, Wardrop CAJ, Holland BM. Infants' blood volume in a controlled trial of placental transfusion at preterm delivery. Pediatrics. 2006;117:93-98.

55. Mercer JS, McGrath MM, Hensman A, Silver H, Oh W. Immediate and delayed cord clamping in infants born between 24 and 32 weeks: a pilot randomized controlled trial. J Perinatol. 2003;23:466-472.

56. Strauss RG, Mock DM, Johnson KJ,et al. Circulating RBC volume, measured with biotinylated RBCs, is superior to the Hct to document the hematologic effects of delayed versus immediate umbilical cord clamping in preterm neonates. Transfusion. 2003;43:1168-1172.

57. Oh W, Carlo WA, Fanaroff AA,et al. Delayed cord clamping in extremely low-birth-weight infants - a pilot randomized controlled trial. Pediatr Res. 2002;51:365-366.

58. Ibrahim HM, Krouskop RW, Lewis DF, Dhanireddy R. Placental transfusion: umbilical cord clamping and preterm infants. J Perinatol. 2000; 20:351-54.

59. Rabe H, Wacker A, Hülskamp G,et al. A randomised controlled trial of delayed cord clamping in very low-birthweight preterm infants. Eur J Pediatr. 2000;159:775-777.

60. Kinmond S, Aitchison TC, Holland BM, Jones JG, Turner TL, Wardrop CA. Umbilical cord clamping and preterm infants: a randomized trial. BMJ. 1993;306:172-175.

61. McDonnell M, Henderson-Smart DJ. Delayed umbilical cord clamping in preterm infants: a feasibility study. J Paediatr Child Health. 1997;33:308-310.

62. Hofmeyr GJ, Gobetz L, Bex PJ,et al. Periventricular/intraventricular hemorrhage following early and delayed umbilical cord clamping. A randomized controlled trial. Online J Curr Clin Trials. 1993;Doc No 110.

63. Hofmeyr GJ, Bolton KD, Bowen DC, Govan JJ. Periventricular/intraventricular haemorrhage and umbilical cord clamping. Findings and hypothesis. S Afr Med J. 1988;73:104-106.

64. Mercer JS, Vohr BR, Erickson-Owens DA, Padbury JF, Oh W. Seven-month developmental outcomes of very low-birthweight infants enrolled in a randomized controlled trial of delayed versus immediate cord clamping. J Perinatol. 2010;30:11-16.

65. American Academy of Pediatrics Subcommittee on Hyperbilirubinemia. Management of hyperbilirubinemia in the newborn infant 35 or more weeks of gestation. Pediatrics. 2004;114:297-316.

66. Georgieff MK. The effect of maternal diabetes during pregnancy on the neurodevelopment of offspring. Minn Med. 2006;89:44-47.
67. Awonusonu FO, Pauly TH, Hutchison AA. Maternal smoking and partial exchange transfusion for neonatal polycythemia. Am J Perinat. 2002;19:349-354.

68. Gordon EA. Polycythemia and hyperviscosity of the newborn. J Perinat Neonatal Nurs. 2003;17:209-219.

69. Pappas A, Delaney-Black V. Differential diagnosis and management of polycythemia. Pediatr Clin North Am. 2004;51:1063-1086, x-xi.

70. Martin RJ, Fanaroff AA, Walsh MC. Fanaroff and Martin's Neonatal-Perinatal Medicine. Diseases of the Fetus and Infant. 8th ed. Philadelphia, PA: Mosby Elsevier; 2006; vol 2:1309.

71. Nelson N, Enkin MW, Saigal S, Bennett KJ, Milner R, Sackett DL. A randomized trial of the Leboyer approach to childbirth. New Engl J Med. 1980;302:655-660.

72. Oxford Midwives Research Group. A study of the relationship between the delivery to cord clamping interval and the time of cord separation. Midwifery. 1991;7:167-176.

73. Geethanath RM, Ramji S, Thirupuram S, Rao YN. Effect of timing of cord clamping on the iron status of infants at three months. Indian Pediatr. 1997;34:103-106.

74. Grajeda R, Perez-Escamilla R, Dewey KG. Delayed clamping of the umbilical cord improves hematologic status of Guatemalan infants at two months of age. Am J Clin Nutr. 1997;65:425-431.

75. de Pee S, Bloem MW, Sari M, Kiess L, Yip R, Kosen S. The high prevalence of low hemoglobin concentration among Indonesian infants aged $3-5$ months is related to maternal anemia. J Nutr. 2002;132:2215-2221.

76. Todorich B, Pasquini JM, Garcia CL, Paez PM, Conner JR Oligodendrocytes and myelination: the role of iron. Glia. 2009;57:467-478.

77. Lozoff B, Jimenez E, Hagen J, Mollen E, Wolf AW. Poorer behavioral and developmental outcome more than 10 years after treatment for iron deficiency in infancy. Pediatrics. 2000;105:E51.

78. Lozoff B, Jimenez E, Smith JB. Double burden of iron deficiency in infancy and low socioeconomic status: a longitudinal analysis of cognitive test scores to age 19 years. Arch Pediatr Adolesc Med. 2006;160:1108-1113.

79. Lozoff B, Clark KM, Jing Y, Armony-Sivan R, Angelilli ML, Jacobson SW. Dose-response relationships between iron deficiency with or without anemia and infant social-emotional behavior. J Pediatr. 2008;152:696-702.

80. Lozoff B, Smith JB, Clark KM, Perales CG, Rivera F, Castillo M. Home intervention improves cognitive and socialemotional scores in iron-deficient anemic infants. Pediatrics. 2010;126:e884-e894.

81. Lozoff B, Beard J, Connor J, Barbara F, Georgieff M, Schallert $\mathrm{T}$. Long-lasting neural and behavioral effects of iron deficiency in infancy. Nutr Rev. 2006;64:S34-S43.

82. Peirano PD, Algar'in CR, Chamorro RA,et al. Sleep alterations and iron deficiency anemia in infancy. Sleep Med. 2010;11:637-642.

83. Burden M, Koss M, Lozoff B. Neurocognitive differences in 19-year-olds treated for iron deficiency in infancy. Pediatr Res. 2004;55:279A.

84. Georgieff MK. Nutrition and the developing brain: nutrient priorities and measurement. Am J Clin Nutr. 2007;85:614S$620 \mathrm{~S}$

85. Rao R, Georgieff MK. Iron in fetal and neonatal nutrition Semin Fetal Neonatal Med. 2007;12:54-63.

86. Lozoff B. Early iron deficiency has brain and behavior effects consistent with dopaminergic dysfunction. J Nutr. 2011;141:740S-746S

87. Tolosa JN, Park DH, Eve DJ, Klasko SK, Borlongan CV, Sanberg PR. Mankind's first natural stem cell transplant. J Cell Mol Med. 2010;14:488-495. 
88. Meier C, Middelanis J, Wasielewski B,et al. Spastic paresis after perinatal brain damage in rats is reduced by human cord blood mononuclear cells. Pediatr Res. 2006;59:244-249.

89. Keller C. Virtual learning environments: three implementation perspectives. Learn Media Technol. 2005;30:299-311.

90. Kattwinkel J, ed. Neonatal Resuscitation (NRP) Textbook. 6th ed. Elk Grove Village, IL: AAP and Am Heart Assocation; 2011

91. Mercer J, Nelson C, Skovgaard RL. Umbilical cord clamping: beliefs and practices of American nurse-midwives. $J$ Midwifery Womens Health. 2000;45:58-66.

92. Mercer J, Skovgaard R, Erickson-Owens D. Fetal to neonatal transition: first, do no harm. In: Downe S, ed. Normal Childbirth: Evidence and Debate. 2nd ed. Edinburgh, Scotland: Churchill Livingstone; 2008.

93. Ewy GA. Cardiocerebral resuscitation: the new cardiopulmonary resuscitation. Circulation. 2005;111:2134-2142.

94. Ewy GA, Kern KB. Recent advances in cardiopulmonary resuscitation; cardiocerebral resuscitation. $\mathrm{J} \mathrm{Am} \mathrm{Coll} \mathrm{Cardiol.}$ 2009;53:149-157.

95. Mercer JS, Erickson-Owens DA, Skovgaard R. Cardiac asystole at birth: is hypovolemic shock the cause? Med Hypotheses. 2009;72:458-463.

96. Asfour V, Bewley S. Might measuring cord $\mathrm{pH}$ in itself affect outcome? BMJ. 2010;341:c4440.

97. Hutchon D. Why do obstetricians and midwives still rush to clamp the cord? BMJ. 2010;341:c5447.

98. Weeks A. Umbilical cord clamping after birth. BMJ 2007;335:312-313.

99. Cashore WJ, Usher R. Hypovolemia resulting from a tight nuchal cord at birth. Pediatr Res. 1973;7:399.

100. Iffy L, Varadi V, Papp E. Untoward neonatal sequelae deriving from cutting of the umbilical cord before delivery. Med Law. 2001;20:627-34.

101. Mercer JS, Skovgaard RL, Peareara-Eaves J, Bowman TA. Nuchal cord management and nurse-midwifery practice. $J$ Midwifery Womens Health. 2005;50:373-379.
102. Vanhaesebrouck P, Vanneste K, de Praeter C, Van Trappen Y, Thiery M. Tight nuchal cord and neonatal hypovolaemic shock. Arch Dis Child. 1987;62:1276-1277.

103. Schorn MN, Blanco JD. Management of the nuchal cord. $J$ Nurse Midwifery. 1991;36:131-132.

104. Mercer J, Erickson-Owens D. The midwifery view of shoulder dystocia. In: O'Leary J, ed. Shoulder Dytocia and Birth Injury. 3rd ed. New York, NY: Humana Press; 2010.

105. Hope P, Bresline S, Lamont L,et al. Fatal shoulder dystocia: a review of 56 cases reported to the Confidential Enquiry into Stillbirths and Deaths in Infancy. BJOG. 1998;105: $1256-1261$.

106. Iffy L, Varadi V. Cerebral palsy following cutting of the nuchal cord before delivery. Med Law. 1994;13:323-330.

107. Flamm BL. Tight nuchal cord and shoulder dystocia: a potentially catastrophic combination. Obstet Gynecol. 1999;94:853.

108. ACOG Committee on Obstetric Practice. ACOG Committee Opinion No. 348, November 2006: umbilical cord blood gas and acid-base analysis. Obstet Gynecol. 2006;108: 1319-1322.

109. Mercer J, Skovgaard R. Neonatal transitional physiology: a new paradigm. J Perinat Neonatal Nurs. 2002;15:56-75.

110. Armstrong L, Stenson B. Use of umbilical cord blood gas analysis in the assessment of the newborn. Arch Dis Child Fetal Neonatal Ed. 2007;02:F430-F434.

111. Paerregaard A, Nickelsen CN, Brandi L, Andersen GE. The influence of sampling site and time upon umbilical cord blood acid-base status and PO2 in the newborn. J Perinat Med. 1987;15:559-563.

112. Brown N. Contraindication of value: between use and exchange in cord blood economy [published online ahead of print 2012]. Social Health Illn. doi:10.1111/j.14679566.2012.01474.x.

113. Shirvani F, Radfar M, Hashemieh M, Soltanzadeh MH, Khaledi H, Mogadam MA. Effect of timing of umbilical cord clamp on newborns' iron status and its relation to delivery type. Arch Iran Med. 2010;13:420-425.

\section{Appendix 1. Literature overview on cord clamping in full-term infants: 2001 to current}

Level IA: Systemic Reviews: 4 Found.

Mathew ${ }^{30}$ : Delayed cord clamping (DCC) does not $\uparrow$ complications for mothers delivering at term. Limited clinical significance for term infants (short and long-term). No evidence of harm.

McDonald and Middleton ${ }^{29}$ : DCC causes no $\uparrow$ in maternal PPH. Growing evidence that DCC improves iron status. Found significantly higher rates of jaundice requiring phototherapy in DCC infants. However, this finding was based on results from two older (1990s) studies only and was not found in most recent studies.

Hutton and Hassan ${ }^{28}$ : Concluded that DCC of at least 2 minutes resulted in improved iron stores at 6 months of age and that polycythemia that may occur as a result of DCC is benign.

van Rheenen and Brabin ${ }^{27}$ : DCC in term infants lead to $\uparrow \mathrm{Hb}$ levels at 2 to 3 months of age and $\downarrow$ the risk of anemia without $\uparrow$ perinatal complications.

Level IIA: Randomized Controlled Trials: 8 Found Plus 2 Secondary Analyses Found 


\section{Appendix 1. Literature overview on cord clamping in full-term infants: 2001 to current (Continued)}

\begin{tabular}{lc}
$\begin{array}{l}\text { Authors } \\
\text { (country of } \\
\text { origin) }\end{array}$ & Study population \\
\hline $\begin{array}{c}\text { Andersson } \\
\text { et al }{ }^{31}\end{array}$ & 400 healthy, term \\
(Sweden) & singleton infants born \\
& after low risk \\
pregnancies and VD; \\
Excluded: serious \\
\\
\\
\\
congenital anomalies \\
and syndromes
\end{tabular}

Ceriani

Cernadas

et al ${ }^{3 y}$

(Argentina)

Secondary

Analysis of

2006 data

Jaleel et al ${ }^{32}$

(Pakistan)

Venancio

et $\mathrm{al}^{33}$

(Brazil)

Jahazi et al ${ }^{34}$ (Iran)

\section{Term infants; no}

complications;

normal pregnancies

Term, singleton

pregnancy; VD or

C/S; Excluded Rh

negative, DM,

Pre-eclampsia and

eclampsia, AP

bleeding, IUGR,

congenital anomalies

325 mother/infant pairs;

term infants; VD; no

congenital anomalies

(article in Portuguese)

EC: immediately after delivery

DCC: after

pulsations

cease

Level: at uterus

EC: DCC: at $1 \mathrm{~min}$

Women 38 to $42 \mathrm{wk}$, singleton pregnancy, uncomplicated pregnancy, unmedicated VD; excludes SGA, LGA, or IUGR, Apgar score $<7$, congenital anomalies
EC: 30 seconds

DCC: at $3 \mathrm{~min}$

Level: at introitus
86

83

83

Serum ferritin (EC 20.9, IC 25.5, DCC 33.2) was significantly higher in DCC than $\mathrm{EC}$ at $6 \mathrm{mo}$. $\mathrm{Hb}$ : EC 10.6, IC 10.8, DCC 10.7 , no differences among groups. Prevalence of IDA $3 \times$ more frequent in the EC group (7.2\%) vs the DCC group (2.4\%).

At birth, EC group had $\uparrow$ incidence of $\mathrm{Hb}<14$ $\mathrm{g} / \mathrm{dL}$ compared with DCC group $(P=$ .008); bili levels at birth and $6 \mathrm{~h}$ were similar $(P=.186)$.

$69 \%$ of infants in study at 3 mo FU; No difference in $\mathrm{Hb}$ levels at 3 mo. DCC significantly higher ferritin at $3 \mathrm{mo}$. $(\uparrow 23.29 \mathrm{ng} / \mathrm{mL}$ in DCC group, $P=.04$ ).

$\mathrm{Hct}$ at $18 \mathrm{~h}$ were: EC $56.9 \%$ vs DCC $56.2 \%, P=.532$.

PRBV significantly higher in EC group $(53.8 \mathrm{ml}$ vs $34.5 \mathrm{ml}$, $P=.001)$.

Asymptomatic poly at $2 \mathrm{~h}: 20$ babies (EC) vs 23 (DCC) $(P=.733)$.
Comments

Largest CC study done in developing country with $92 \%$ FU rate. DCC improves iron status and $\downarrow$ prevalence of IDA at $4 \mathrm{mo}$.

DCC did not $\uparrow$ risk ivi nuiy, jaur Iuice requiring phototherapy or respiratory symptoms; Blood gas collected $(\sim 30$ s) UII all IIIIallis.

Excellent follow-up rate of $92.4 \%$. DCC at 3 min significantly increases serum ferritin levels at 6 mo of age. No differences in $\mathrm{Hb}$ levels. Findings consistent with other studies.

DCC results in higher $\mathrm{Hb}$. EC group had higher incidence of anemia at $6 \mathrm{~h}$. No harm was noted.

DCC can be used as a strategy to improve infant iron stores out to $3 \mathrm{mo}$ of age.

18-h Hct similar between groups yet great amount of PRBV blood was drained from EC group.

No differences in asymptomatic poly between groups.

(continues) 
Appendix 1. Literature overview on cord clamping in full-term infants: 2001 to current (Continued)

\begin{tabular}{|c|c|c|c|c|}
\hline $\begin{array}{l}\text { Authors } \\
\text { (country of } \\
\text { origin) }\end{array}$ & Study population & $\begin{array}{c}\text { Cord } \\
\text { management } \\
\text { placement of } \\
\text { infant }\end{array}$ & $\begin{array}{c}\text { Sample } \\
\text { size }\end{array}$ & Significant results \\
\hline $\begin{array}{l}\text { Chaparro } \\
\text { et al }{ }^{40} \\
\text { (Mexico) } \\
\text { Secondary } \\
\text { Analysis of } \\
2006 \text { data }\end{array}$ & $\begin{array}{l}\text { Subset of women } \\
\text { and infants from } \\
\text { the } 2006 \text { study }\end{array}$ & $\begin{array}{l}\text { EC: at } 10 \mathrm{~s} \\
(\times 16.5) \\
\text { DCC: at } 2 \min (94 \\
\text { s) } \\
\text { Level: at the } \\
\text { uterus }\end{array}$ & $\begin{array}{l}127 \\
139\end{array}$ & $\begin{array}{ll}\text { EC by lowering infant iron Used regression statistics } \\
\text { status contributed to } & \text { to control for many } \\
\text { higher lead levels at } 6 & \text { potentially confounding } \\
\text { mo of age in infants at } & \text { variables. Lower iron } \\
\text { risk. } & \text { stores may allow for } \\
& \text { greater uptake of lead. }\end{array}$ \\
\hline $\begin{array}{l}\text { van Rheenen } \\
\text { et } \mathrm{al}^{14} \\
\text { (Zambia) }\end{array}$ & $\begin{array}{l}\text { Women at term, } \\
\text { singletons, normal } \\
\text { pregnancies. } \\
\text { Infants excluded } \\
\text { after birth if nuchal } \\
\text { cord, anomalies or }\end{array}$ & $\begin{array}{l}\text { EC: }<20 \text { s } \\
\text { DCC: after } \\
\text { pulsations } \\
\text { cease } \\
\text { Level: below } \\
\text { introitus at } 10\end{array}$ & $\begin{array}{l}45 \\
46\end{array}$ & $\begin{array}{l}\text { Infants with } \mathrm{EC} \text { had more } \mathrm{Hb} \text { alone may not be an } \\
\text { anemia at } 4 \mathrm{mo} \text {. of age adequate measure of } \\
\text { (OR 0.3). No } \uparrow \text { in poly or iron stores. } \\
\text { jaundice. Follow-up up DCC offers a strategy to } \\
\text { to } 6 \text { mo showed no } \quad \text { reduce early infant } \\
\text { difference in Hb or ZPP. anemia. }\end{array}$ \\
\hline
\end{tabular}

\begin{tabular}{|c|c|c|}
\hline $\begin{array}{l}\text { Chaparro } \\
\text { et al }{ }^{35} \\
\text { (Mexico) }\end{array}$ & $\begin{array}{l}\text { Women } 37-42 \text { wk; } \\
\text { early labor, } \\
\text { singleton } \\
\text { pregnancy, VD, } \\
\text { normal } \\
\text { pregnancies, plan } \\
\text { BF for } 6 \text { mo, no } \\
\text { smokers; no IUGR } \\
\text { or major }\end{array}$ & $\begin{array}{l}\text { EC: at } 10 \mathrm{~s} \\
(\times 16.5) \\
\text { DCC: at } 2 \mathrm{~min}(94 \\
\text { s) } \\
\text { Level: at the } \\
\text { uterus }\end{array}$ \\
\hline
\end{tabular}

171

187

Primary outcome: At 6 mo, Largest study to date to DCC infants had higher look at any long-term $\operatorname{MCV}(79.5$ vs $81, P=$ outcomes.

.001 ), ferritin (51 vs 34 Conservative in that they $\mathrm{mcg} / \mathrm{L}, P=.0002)$, and used only a 2-min delay. total body iron (48 vs 44, No significant

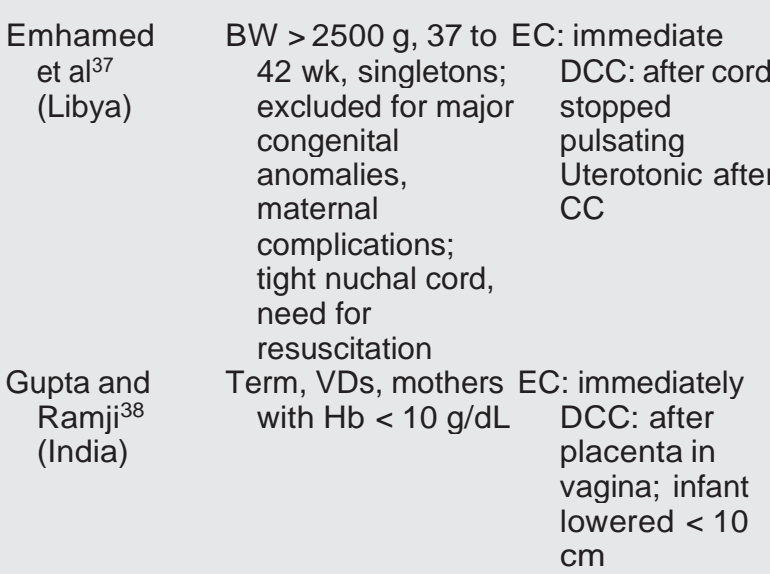

45

57

$$
\begin{array}{cl}
\text { Shirvani } & \text { Healthy infants } \geq 35 \text { EC: } \leq 15 \mathrm{~s} \\
\text { et al }^{113} \text { (Iran) } & \text { wk; born by VD or DCC: }>15 \mathrm{~s} \\
& \mathrm{C} / \mathrm{S} \text {; } \\
& \begin{array}{l}
\text { uncomplicated } \\
\text { pregnancies }
\end{array}
\end{array}
$$
$P=.0003)$ than $\mathrm{EC}$ infants. Hct $<70 \%$ : EC $8 \%$ vs DCC $13 \% P<$ .15. Jaundice: EC 14\% vs DCC $17 \% P \leq .36$.

\section{DCC infants had} significantly higher Hct (53 vs 49\%, $P=.004)$ and $\mathrm{Hb}(17.1$ vs 18.5 $(P=.0005) .3$ DCC infants had poly with no symptoms; 2 EC infants needed phototherapy.

\section{differences in $\mathrm{Hb}$ or $\mathrm{Hct}$} at 6 mo although differences evident in the newborn period (Hct $60 \%$ vs $62 \%, P=.003$ ). No harmful effects seen. No perinatal complications from DCC in this study.

At 3 mo, infant mean OR for anemia $7 x$ greater ferritin and $\mathrm{Hb}$ results $\uparrow$ in EC group at 3 mo of with DCC: ferritin (118.4 age.
$\mu \mathrm{g} / \mathrm{L}$ vs $73 \mu \mathrm{g} / \mathrm{L}, P=$
$.02), \mathrm{Hb}(9.9 \mathrm{~g} / \mathrm{L}$ vs 8.8
DCC especially benefits $\mathrm{g} / \mathrm{L}, P<.001)$.
infants born to anemic mothers.

$\mathrm{Hb}$ levels at $48 \mathrm{~h}$ were $\uparrow$ in Findings suggest DCC

$\begin{array}{ll}\text { DCC group }(P<.005) . & \text { results in } \uparrow \mathrm{Hb} \text { in VD and } \\ \text { No poly reported; no } & \mathrm{C} / \mathrm{S} \text { at } 48 \mathrm{~h} \text { of age; No } \\ \text { evidence of NICU } & \text { harm was found } \\ \begin{array}{l}\text { admission or need for } \\ \text { phototherapy to treat }\end{array} \\ \text { jaundice. }\end{array}$
jaundice.

Abbreviations: AP, antepartum; BF, breastfeeding; bili, bilirubin; BV, blood volume; BW, birth weight; CC, cord clamping; C/S, Cesarean Section; DCC, delayed cord clamping; DM, diabetes; EC, early clamping; Hb, hemoglobin; Hct, hematocrit; IC, immediate clamping; IDA, iron deficiency anemia; IUGR, intrauterine growth restriction; LC, late clamping; LGA, large for gestational age; MCV, mean corpuscular volume; OR, odds ratio; poly, polycythemia; $\mathrm{PPH}$, postpartum hemorrhage; PRBV, placental residual blood volume; ReIR, relative risk; SGA, small for gestational age; VD, vaginal delivery; ZPP, zinc protoporphyrin. Reprinted with permission from Normal Childbirth. Evidence and Debate. ${ }^{92}$ Copyright 2008, Churchill Livingstone Elsevier. 
Appendix 2. Incidence of jaundice and polycythemia with cord clamping in full-term infants: 1980 to current (randomized controlled trials)

\begin{tabular}{|c|c|c|c|c|c|c|c|c|}
\hline \multirow{2}{*}{$\begin{array}{l}\text { Authors } \\
\text { (country of } \\
\text { origin) }\end{array}$} & \multirow{2}{*}{$\begin{array}{c}\text { Study } \\
\text { population }\end{array}$} & \multirow{2}{*}{$\begin{array}{c}\text { Cord } \\
\text { management }\end{array}$} & \multirow{2}{*}{$\begin{array}{l}\text { Sample } \\
\text { size }\end{array}$} & \multirow[b]{2}{*}{ Benefits of DCC } & \multirow{2}{*}{$\begin{array}{l}\text { Incidence of } \\
\text { jaundice }\end{array}$} & \multicolumn{2}{|c|}{ Polycythemia } & \multirow[b]{2}{*}{ Comments } \\
\hline & & & & & & Symptomatic & No symptoms & \\
\hline $\begin{array}{l}\text { Andersson } \\
\text { et } \mathrm{al}^{31} \\
\text { (Sweden) }\end{array}$ & $\begin{array}{l}\text { Term infants, } \\
\text { normal } \\
\text { pregnancies }\end{array}$ & $\begin{array}{l}\text { IC: }<10 \mathrm{~s} \\
\text { DCC: }>180 \mathrm{~s} \\
\text { Infants lowered } \\
\times 20 \mathrm{~s} \text { then on } \\
\text { maternal } \\
\text { abdomen. }\end{array}$ & $\begin{array}{l}189 \leq \\
192\end{array}$ & $\begin{array}{l}\text { Serum ferritin levels at } 7 \\
4 \text { mo of age } 45 \% \\
\text { higher in the DCC } \\
\text { group }(117 \mu \mathrm{g} / \mathrm{L} \text { vs } \\
81 \mu \mathrm{g} / \mathrm{L}, P<.001) . \\
\text { DCC infant BW was } \\
\text { heavier. }\end{array}$ & $\begin{array}{l}\text { Total serum bili (>15 } \\
\text { mg/dL) IC } 7 \text { vs } \\
\text { DCC } 4 \text { (NS); } \\
\text { Phototherapy } \\
\text { needed by } 2 \text { in IC } \\
\text { and1 in DCC } \\
\text { group. }\end{array}$ & 5 & 0 & $\begin{array}{l}\text { Largest study in a } \\
\text { developed } \\
\text { country to date. }\end{array}$ \\
\hline $\begin{array}{l}\text { Ceriani Cernadas } \\
\text { et } \mathrm{al}^{36,39} \\
\text { (Argentina) }\end{array}$ & $\begin{array}{l}\text { Term infants; no } \\
\text { complications; } \\
\text { normal } \\
\text { pregnancies }\end{array}$ & $\begin{array}{l}\text { EC: within } 15 \mathrm{~s} \\
\text { IC: at } 1 \mathrm{~min} \\
\text { DCC: } 3 \mathrm{~min} \\
\text { Infants lowered }\end{array}$ & $\begin{array}{l}86 \\
83 \\
83\end{array}$ & $\begin{array}{l}\text { Serum ferritin } \\
\text { significantly higher in } \\
\text { DCC group at } 6 \text { mo. } \\
\text { Anemia (IDA) } 3 \text { times } \\
\text { more frequent in the } \\
\text { EC group at } \\
6 \text { h. } \\
\text { DCC infant BW was } \\
\text { heavier. }\end{array}$ & $\begin{array}{l}E C=2 ; I C=1 ; D C C \\
=0(N S)\end{array}$ & E & $\begin{array}{l}\text { EC 2; IC 4; DCC } 7 \\
\text { at } 6 \text { h of age. No } \\
\text { symptoms and no } \\
\text { treatment was } \\
\text { needed. }\end{array}$ & $\begin{array}{l}\text { DCC at } 3 \text { min } \\
\text { significantly } \\
\text { increases } \\
\text { serum ferritin } \\
\text { levels at } 6 \text { mo } \\
\text { of age. }\end{array}$ \\
\hline $\begin{array}{l}\text { Chaparro et } \mathrm{al}^{35} \\
\text { (Mexico) }\end{array}$ & $\begin{array}{l}\text { Term, single, } \\
\text { normal } \\
\text { pregnancy, } \\
\text { vaginal birth, } \\
\text { plan BF for } 6 \\
\text { mo, no } \\
\text { smokers }\end{array}$ & $\begin{array}{l}\text { EC: at } 10 \mathrm{~s} \text { DCC: } \\
\text { at } 2 \text { min }(94 \mathrm{~s} \\
\text { average) } \\
\text { Level: at the } \\
\text { perineum }\end{array}$ & $\begin{array}{l}171+ \\
187\end{array}$ & $\begin{array}{l}\text { At } 6 \text { mo, DCC infants } \\
\text { had significantly } \\
\text { higher MCV, ferritin, } \\
\text { and total body iron } \\
\text { than EC infants. }\end{array}$ & $\begin{array}{l}\text { Clinical jaundice: EC } \\
14 \% \text { vs DCC } 17 \% \\
P \leq .36 \text { (NS); no } \\
\text { report of } \\
\text { phototherapy } \\
\text { needed. }\end{array}$ & 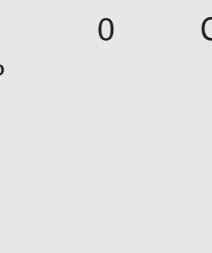 & $\begin{array}{l}\text { Capillary sample: } 8 \% \\
\text { in EC group; } 13 \% \\
\text { in DCC group; } \\
\text { venous sample } \\
\text { found EC 0; DCC } 2 \\
\text { no treatment } \\
\text { needed. }\end{array}$ & $\begin{array}{l}\text { No harmful } \\
\text { effects seen. }\end{array}$ \\
\hline $\begin{array}{l}\text { van Rheenen } \\
\text { et }^{1 l^{14}} \text { (Zambia) }\end{array}$ & $\begin{array}{l}\text { Term, single, } \\
\text { normal } \\
\text { pregnancies }\end{array}$ & $\begin{array}{l}\text { EC: }<20 \text { s DCC: } \\
\text { after pulsations } \\
\text { cease } \\
\text { Level: below } \\
\text { introitus at } 10 \\
\text { cm }\end{array}$ & $\begin{array}{l}45 \\
46\end{array}$ & $\begin{array}{l}\text { Infants with EC had } \\
\text { more anemia at } 4 \text { mo } \\
\text { of age (OR } 0.3) \text {. }\end{array}$ & 0 & 5 & $\begin{array}{l}5 \% \text { in each group } \\
\quad(\mathrm{PCV}>0.70) ; \text { no } \\
\text { symptoms and no } \\
\text { treatment } \\
\text { indicated. }\end{array}$ & $\begin{array}{l}\text { DCC offers a } \\
\text { strategy to } \\
\text { reduce early } \\
\text { infant anemia. }\end{array}$ \\
\hline 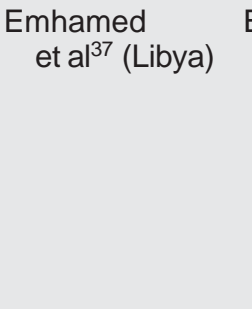 & $\begin{array}{l}\text { BW > } 2500 \mathrm{~g}, \\
37 \text { to } 42 \mathrm{wk}, \\
\text { singletons; } \\
\text { excluded for } \\
\text { congenital } \\
\text { anomalies, } \\
\text { maternal } \\
\text { complications }\end{array}$ & $\begin{array}{l}\text { EC: immediate } \\
\text { DCC: after cord } \\
\text { stopped } \\
\text { pulsating }\end{array}$ & $\begin{array}{l}45 \\
57\end{array}$ & $\begin{array}{l}\text { DCC infants had } \\
\text { significantly higher } \\
\mathrm{Hct} \text { and } \mathrm{Hb} \text { at } 24 \mathrm{~h} \text {. }\end{array}$ & $\begin{array}{l}2 \text { EC infants needed } \\
\text { phototherapy. }\end{array}$ & 0 & $\begin{array}{l}3 \text { DCC infants had } \\
\text { polycythemia with } \\
\text { no symptoms. }\end{array}$ & $\begin{array}{l}\text { No perinatal } \\
\text { complications } \\
\text { from DCC in } \\
\text { this study. }\end{array}$ \\
\hline
\end{tabular}




\section{Appendix 2. Incidence of jaundice and polycythemia with cord clamping in full-term infants: 1980 to current (randomized}

controlled trials) (Continued)

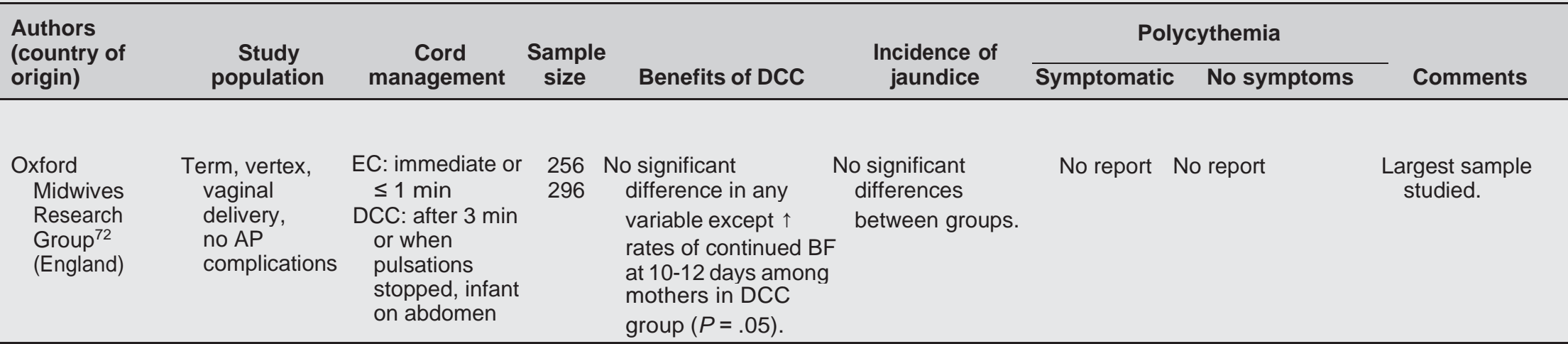

Abbreviations: AP, antepartum; BF, breastfeeding; bili, bilirubin; BW, birth weight; DCC, delayed cord clamping; EC, early clamping; Hb, hemoglobin; Hct = hematocrit; IC, immediate clamping; IDA, iron deficiency anemia; LC, late clamping; MCV, mean corpuscular volume; NS, not significant; OR, odds ratio; PCV, packed cell volume. 